AperTO - Archivio Istituzionale Open Access dell'Università di Torino

Detection of volatile metabolites of moulds isolated from a contaminated library

This is a pre print version of the following article:

Original Citation:

Availability:

This version is available http://hdl.handle.net/2318/1584272

since 2017-05-11T18:33:10Z

Published version:

DOI:10.1016/j.mimet.2016.07.004

Terms of use:

Open Access

Anyone can freely access the full text of works made available as "Open Access". Works made available under a Creative Commons license can be used according to the terms and conditions of said license. Use of all other works requires consent of the right holder (author or publisher) if not exempted from copyright protection by the applicable law. 
This Accepted Author Manuscript (AAM) is copyrighted and published by Elsevier. It is posted here by agreement between Elsevier and the University of Turin. Changes resulting from the publishing process - such as editing, corrections, structural formatting, and other quality control mechanisms - may not be reflected in this version of the text. The definitive version of the text was subsequently published in JOURNAL OF MICROBIOLOGICAL METHODS, 128, 2016, 10.1016/j.mimet.2016.07.004.

You may download, copy and otherwise use the AAM for non-commercial purposes provided that your license is limited by the following restrictions:

(1) You may use this AAM for non-commercial purposes only under the terms of the CC-BY-NC-ND license.

(2) The integrity of the work and identification of the author, copyright owner, and publisher must be preserved in any copy.

(3) You must attribute this AAM in the following format: Creative Commons BY-NC-ND license (http://creativecommons.org/licenses/by-nc-nd/4.0/deed.en), 10.1016/j.mimet.2016.07.004

The publisher's version is available at:

http://linkinghub.elsevier.com/retrieve/pii/S0167701216301762

When citing, please refer to the published version.

Link to this full text:

http://hdl.handle.net/2318/1584272 


\title{
Detection of volatile metabolites of moulds isolated from a contaminated library
}

\author{
Anna Micheluz $^{\mathrm{a}, *}$, Sabrina Manente ${ }^{\mathrm{b}}$, Manuela Rovea ${ }^{\mathrm{c}}$, Debora Slanzi ${ }^{\mathrm{a}}$, Giovanna Cristina Varese ${ }^{\mathrm{d}}$, \\ Giampietro Ravagnan ${ }^{\mathrm{b}}$, Gianmaria Formenton ${ }^{\mathrm{c}}$ \\ ${ }^{a}$ Department of Environmental Sciences, Informatics and Statistic, Ca1' Foscari University, Via Torino 155, 30172 Mestre, Venice, Italy \\ ${ }^{\mathrm{b}}$ Department of Molecular Sciences and Nanosystems, Ca' Foscari University, Via Torino 155, 30123 Mestre, Venice, Italy \\ c Dipartimento Regionale Laboratori, Agenzia Regionale per la Prevenzione e Protezione Ambientale del Veneto, Via Lissa 6, 30174 Mestre, Venice, Italy \\ ${ }^{\mathrm{d}}$ Department of Life Sciences and Systems Biology, University of Turin, Viale Mattioli 25, 10125 Turin, Italy
}

\section{A R T I C L E IN F O}

\section{Article history:}

Received 3 May 2016

Received in revised form 4 July 2016

Accepted 4 July 2016

Available online $\mathrm{xxx}$

Keywords:

MVOCs

indoor air

contaminated library

Eurotium halophilicum

\section{A B S T R A C T}

The principal fungal species isolated from a contaminated library environment were tested for their microbial volatile organic compound (MVOC) production ability. Aspergillus creber, A. penicillioides, Cladosporium cladosporioides, Eurotium chevalieri, E. halophilicum, Penicillium brevicompactum and P. chrysogenum were cultivated on suitable culture media inside sample bottles specifically designed and created for direct MVOC injection to a GC-MS instrument. The fungal emissions were monitored over several weeks to detect changes with the aging of the colonies, monitored also by respirometric tests. A total of 55 different MVOCs were detected and isopropyl alcohol, 3-methyl-1-butanol and 2-butanone were the principal compounds in common between the selected fungal species. Moreover, 2,4-dimethylheptane, 1,4-pentadiene, styrene, ethanol, 2-methyl-1-butanol, acetone, furan and 2-methylfuran were the most detected compounds. For the first time, the MVOC production for particular fungal species was detected. The species $A$. creber, which belongs to the recently revised group Aspergillus section Versicolores, was characterized by the production of ethanol, furan and 1,4-pentadiene. For the xerophilic fungus E. halophilicum, specific production of acetone, 2-butanone and 1,4-pentadiene was detected, supported also by respirometric data. The results demonstrated the potential use of this method for the detection of fungal contamination phenomena inside Cultural Heritage's preservation environments.

(C) 2016 Published by Elsevier Ltd

\section{Introduction}

The study of microbial volatile organic compounds (MVOCs) produced by moulds developed in indoor environments has been addressed by several authors, especially in relation with dampness situations and possible human health problems (Cabral, 2010; Moularat et al., 2008; Polizzi et al., 2009; Wady et al., 2003). Since the 1990s, MVOCs are often discussed to be associated with the sick building syndrome (SBS) because of their suspected role as responsible for a wide range of specific and non-specific symptoms and discomfort (Elke et al., 1999; Larsen et al., 1998; Matysik et al., 2008; Meyer et al., 1998; Wessén and Schoeps, 1996).

In the recent years, MVOCs started to be considered also for cases concerned the preservation of Cultural Heritage, as biodeterioration phenomena interested archive and library collections (Joblin et al., 2010; Pinzari et al., 2004). Fungal contamination became a frequent and complex problem to manage, often with severe, economic and health implications (Montanari et al., 2012). However, the majority of previous studies were mainly focused on the detection of chemical markers specifically related to the natural degradation of the book

\footnotetext{
* Corresponding author.

Email addresses: anna.micheluz@unive.it (A. Micheluz); manente@unive.it (S. Manente); manuela.rovea@arpa.veneto.it (M. Rovea); debora.slanzi@unive.it (D. Slanzi); cristina.varese@unito.it (G.C. Varese); gprav@unive.it (G. Ravagnan); gianni.formenton@arpa.veneto.it (G. Formenton)
}

and paper components (Fenech et al., 2010; Lattuati-Derieux et al., 2004; Strilič et al., 2009, 2010).

The preservation of art collections starts from the performed prevention features, and MVOCs could serve as general early indicators of potential biocontamination problems (Pinzari et al., 2004). In fact, these compounds originate from both fungal primary and secondary metabolite production, strictly depending on the fungal species, the substrate and in according to the different fungal growing phases (Korpi et al., 2009; Matysik et al., 2008; Polizzi et al., 2009). Several alcohols, e.g. 1-octen-3-ol and 3-octanol, as well as ketones and furans were addressed as indicators of mould, recognised both on pure culture studied, on agar substrate, and on wallpaper and building materials (Polizzi et al., 2012). Aspergillus and Penicillium are the most investigated fungal genera in MVOC studies (Fiedler et al., 2001; Matysik et al., 2008, 2009; Moularat et al., 2008; Polizzi et al., 2012; Schuchardt and Kruse, 2009; Wady et al., 2003, Wady and Larsson, 2005) because of their ubiquity in indoor environments (Cabral, 2010; Samson et al., 2004), also in association with the biodeterioration of Cultural Heritage (Micheluz et al., 2015; Sterflinger, 2010; Zyska, 1997). However, in the recent years, specific fungal contamination emerged inside Italian archives and library, mainly caused by a xerophilic fungus with a lack of knowledge about its MVOC emission capability, i.e. E. halophilicum (Micheluz et al., 2015; Montanari et al., 2012; Pinzari and Montanari, 2011).

The determination of MVOCs is usually accomplished by gas chromatography-mass spectrometry (GC-MS) because of its power- 
ful separation capability and highly sensitive detection performance (Matysik et al., 2009). Different sampling methods have been commonly used for sampling volatiles, as headspace solid-phase microextraction (HP-SPME) and Tenax desorption tubes, Tenax ${ }^{\circledR}$ TA, because of their low-costs and as rapid tool to determine very low quantities of a wide range of analytes (Fiedler et al., 2001; Matysik et al., 2008; Schuchardt and Kruse, 2009). Recently, other passive devices were developed specifically for long-term study requirements, as adsorbents based on activated charcoal (Matysik et al., 2009) or PDMS strips (Gibson et al., 2012). Other kind of technique is based on the MVOCs detection by sensor-based devices, e.g. polymer sensors responsive to variation in electrical conductivity due to VOC adsorption (Joblin et al., 2010) or electron noses (e-noses), based on rapid detection and identification of a preselected range of volatile compounds (Kuske et al., 2005; Pinzari et al., 2004).

Most of the sampling techniques require a support device for the volatile compound captures, a desorption system and, often, a pre-selection of detectable compounds. In order to avoid these steps and to permit the analysis of the total air composition, with the specific aim to prevent chemical artefact formation, an alternative air sampling system was presented. Based on EPA TO-15 (1999), ad-hoc fungal culture bottles were developed for the analysis of several fungal species isolated from a contaminated library by GC-MS. As a result of a previous work (Micheluz et al., 2015), Aspergillus creber, A. penicillioides, Cladosporium cladosporioides, Eurotium chevalieri, E. halophilicum, Penicillium brevicompactum and P. chrysogenum were tested for their MVOC production. The aim of this work was to highlight specific chemical compounds for each fungal species, comparing the results with data available in literature and improving the knowledge for the species, which never have been screened before for their volatile compound production.

\section{Materials and methods}

\subsection{Study site}

The study was focused on a repository of the Library of Humanities (Biblioteca di Area UManistica, BAUM), at Ca' Foscari University, Palazzo Malcanton Marcorà, in Venice (Italy), in which a spreading fungi contamination interested $>27,000$ books belonging to the Historical collections. Located in the second underground floor, the repository covers an area of about $150 \mathrm{~m}^{2}$ and is furnished with 50 Compactus ${ }^{\circledR}$ shelves.

\subsection{Sampling and fungal identification}

The mycological sampling was performed for the detection of the viable airborne fungal load and for the isolation of fungi grown on books. Five sampling areas were chosen inside and outside of the repository, as reported in the previous study by Micheluz et al. (2015). Air sampling was performed in active mode by Sampl'air Lite sampler (Biomérieux, Florence, Italy) in three replicates with 9-cm Petri dishes containing different media (Malt Extract Agar, MEA and Malt Extract Agar added with $15 \%$ of $\mathrm{NaCl}$, MEA15\%, purchased at Fluka, Sigma-Aldrich), flow rate $100 \mathrm{~L} \mathrm{~min}^{-1}$ and sample volume of $100 \mathrm{~L}$. Contaminated books were sampled by sterile cotton swabs (Cultiplast, PL ItalianaSpa, Milan, Italy) wiped on book covers and then inoculated onto 9-cm Petri dishes. Fungal identifications were based on macroscopic and microscopic features and confirmed by molecular techniques (Micheluz et al., 2015, 2016). All the fungal strains are preserved at the Mycotheca Universitatis Taurinensis (MUT) of the Department of Life Sciences and System Biology, University of Turin (Italy).

\subsection{Selection of fungal species and culture conditions}

Among 36 mould species isolated from the repository (Micheluz et al., 2015), 7 fungal strains were selected for their MVOC production ability (Table 1). Aspergillus creber, A. penicillioides, Cladosporium cladosporioides, Eurotium chevalieri, E. halophilicum, Penicillium brevicompactum and $P$. chrysogenum were selected on the base of their isolation frequency, their occurrence in indoor air/on contaminated books and a lack of knowledge about their MVOC production.

All fungal strains were cultivated inside $1 \mathrm{~L}$ glass bottles with an area of about $64 \mathrm{~cm}^{2}$ and $100 \mathrm{~mL}$ of medium. As a result of previous selection media (Christensen et al., 1959; Micheluz et al., 2015) three replicas of each strain of fungi were inoculated onto MEA, except $E$. halophilicum and $A$. penicillioides samples which were cultivated onto the selective low water activity medium MEA $15 \%$. As reported in Fig. 1, each bottle was closed with a cap composed of two thermoresistent plastic tubes: the first tube was furnished with a Swagelok connector as direct connection with GC-MS instrument, while the second tube was equipped with a activated charcoal tube (Standard Charcoal tubes ORBO ${ }^{\mathrm{TM}}, 32$, Supelco) and $0.2 \mu \mathrm{m}$ filter (IC Millex ${ }^{\circledR}-L G$, Millipore Corp., Carrigtwohill, Co.Cork, Ireland) to permit the regulation of the inside pressure after each sampling. The bottles were incubated in a dark place at $25^{\circ} \mathrm{C}$ for $1-2$ months. Samples bottles filled with non-inoculated MEA and MEA15\% media were used as blanks.

\subsection{MVOCs pre-concentration}

In order to detect the MVOCs production, a direct tube with Swagelok connection was established between the sampling bottle and the microscale purge \& trap Entech 7100 system (Entech Instrument, Inc). For each analysis, $40 \mathrm{~mL}$ of sample and $100 \mathrm{~mL}$ of internal standards (I.S.) spiking mixture of $20 \mu \mathrm{g} \mathrm{m}^{-3}$ (1,4-bromofluorobenzene, 1,4-difluorobenzene, bromochloromethane and chlorobenzene- $\mathrm{d}_{5}$ ) were suctioned separately with a pump, controlled by a mass flow controller, and injected together inside the pre-concentrator system in order to quantified the unknown compounds using the internal standard method. The I.S. was prepared from $1 \mathrm{mg} \mathrm{m}^{-3}$ of certificated mixture (SIAD, certificated mixture with $6 \%$ of uncertainty) and the compounds were selected because of their non-interfering behaviour with environmental and fungal VOCs (Rovea et al., 2013). The concentration of the sample was carried out

Table 1

List of fungal species isolated from the contaminated repository and selected for MVOC analysis. MUT and GenBank ${ }^{\circledR}$ accession numbers are included.

\begin{tabular}{lclc}
\hline & MUT & GenBank® accession & \\
Fungal species & no. & number & Source \\
\hline Aspergillus creber Juriević, S.W. & MUT & KU179486 & Book \\
Peterson \& B.W. Horn & 470 & & cover \\
Aspergillus penicillioides Spegazzini & MUT & KU179489 & Book \\
& 481 & & cover \\
Cladosporium cladosporioides & MUT & KU179495 & Indoor \\
(Fresen) G.A. de Vries & 527 & & air \\
Eurotium chevalieri L. Mangin & MUT & $(*)$ & Indoor \\
& 472 & & air \\
& MUT & KM502179 & Book \\
Eurotium halophilicum C.M. Chr., & 482 & & cover \\
Papav. \& C.R. Benj. & MUT & KM502183 & Book \\
Penicillium brevicompactum Dierckx & 536 & & cover \\
& MUT & KM502200 & air \\
Penicillium chrysogenum Thom & 5493 & & air \\
& & & \\
\hline
\end{tabular}

(*) Fungal strain without deposited sequence in GenBank® because of its low quality. 


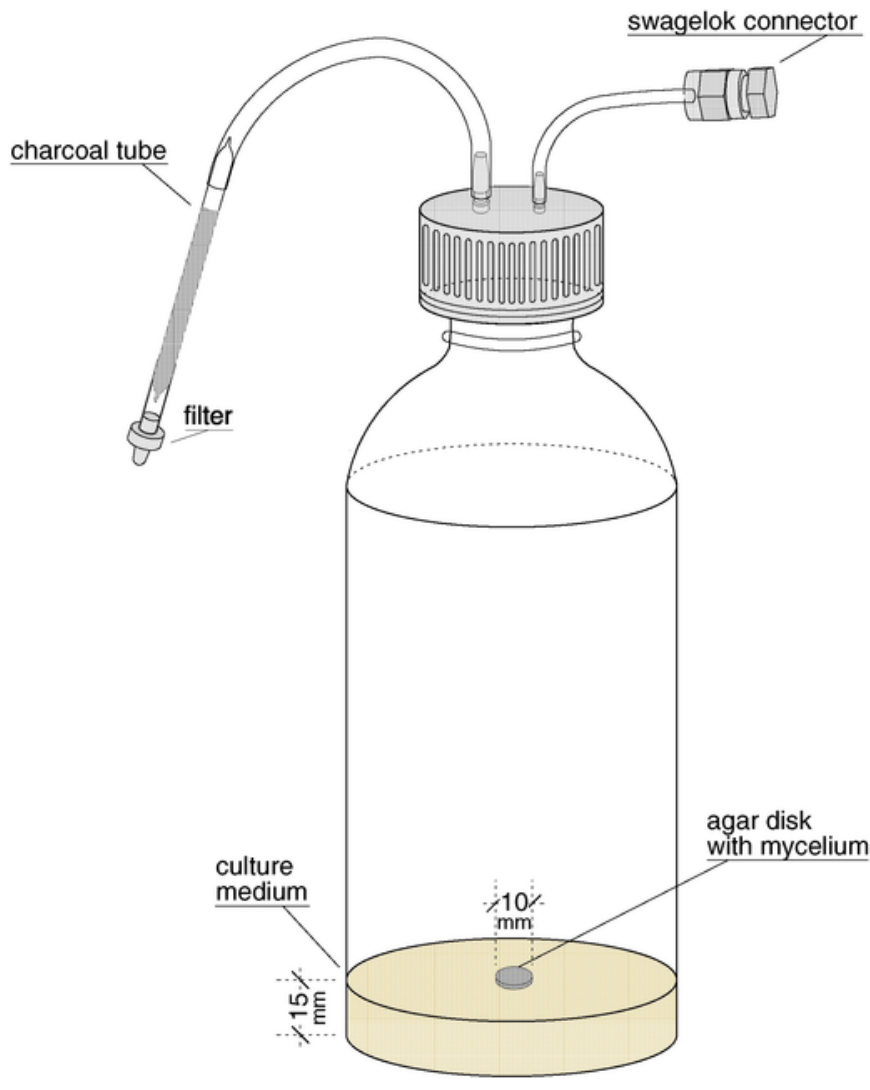

Fig. 1. Sample bottle for MVOC analysis of fungal culture.

in successive stages inside the Entech pre-concentrator, starting in the module 1, consisting of a trap with glass microspheres cooled to $-150{ }^{\circ} \mathrm{C}$ with liquid nitrogen. VOCs with water and carbon dioxide were quantitatively blocked, while the main air constituents, i.e. oxygen, nitrogen and argon, were discharged. After that, the module 1 was heated to $10^{\circ} \mathrm{C}$ and the VOCs were transferred to module 2, a Tenax trap, provided with helium stream and cooled to $-30^{\circ} \mathrm{C}$. In this passage, carbon dioxide was discharged, while water remained in the module 1. The VOCs were adsorbed on the Tenax resin, because of their high affinity. By heating at $180{ }^{\circ} \mathrm{C}$, the VOCs were thermally desorbed from module 2 and transferred to module 3 , which is constituted by a cryofocuser cooled to $-150{ }^{\circ} \mathrm{C}$ with liquid nitrogen. Finally, the module 3 was quickly heated and the analytes were transferred to the gas chromatographic column.

\subsection{Gas chromatography-mass spectrometry (GC-MS)}

Analysis was carried out with Autosystem XL gas chromatographic system equipped with Mass-Gold quadrupole mass spectrometer (both Perkin Elmer Inc. USA) and Turbo Mass vers. 5.4.2 as acquisition software. For separation, an Equity 1 capillary (Supelco, $60 \mathrm{~m}, 0.32 \mathrm{~mm}$ i.d., $1 \mu \mathrm{m} \mathrm{df}$ ) with helium as carrier gas was used. The GC oven program was chosen according to the following scheme: $40{ }^{\circ} \mathrm{C}$ for $6 \mathrm{~min}, 10^{\circ} \mathrm{C} / \mathrm{min}$ up to $250^{\circ} \mathrm{C}$ and $250{ }^{\circ} \mathrm{C}$ for $5 \mathrm{~min}$. For MS detection electron ionization (EI) with $70 \mathrm{eV}$ was applied and mass fragments were detected between 33 and $270 \mathrm{~m} / \mathrm{z}$ in the total ion current mode (TIC). A reference standard library (NIST MS Search 2.0, National Institute of Standards and Technology) was used to identify the volatiles.

\subsection{Fungal respirometric analysis}

The biological activity of each fungus was measured indirectly by the manometric method. The fungi were inoculated in $1 \mathrm{~L}$ septum sealed nozzle bottles filled with $100 \mathrm{~mL}$ of MEA medium, with the exception for E. halophilicum and A. penicillioides which MEA15\% medium was used. All the bottles were closed with a pressure sensor mounted on top (OxiTop®-C system, WTW, Weilheim, Germany) and incubated for $25-35 \mathrm{~d}$ at $25^{\circ} \mathrm{C}$. The carbon dioxide evolved during aerobic respiration was quantitative adsorbed using droplets of $\mathrm{NaOH}$ (Carlo Erba Reagents, Milan, Italy) inside the sealed nozzle septum of the bottles. The pressure drop detected (every $100 \mathrm{~min}$ ) in the bottle was proportional to the amount of oxygen used by fungi (Pereira et al., 2014; Schuchardt and Kruse, 2009; Willcock and Magan, 2001).

\section{Results}

The MVOC production was monitored from the inoculum to the idiophase of the fungal colonies, in particular after 3, 6, 12, 19 and 24 days after inoculation. For A. penicillioides and E. halophilicum, the monitoring started after 6 days, because of their slow growth, and extended with weekly analyses until 28 days for $A$. penicillioides and until 60 days for E. halophilicum.

During the monitoring period, we detected the appearance and the growth of many compounds, and the disappearance of others (i.e. all the aldehydes of the culture media). $>100$ chromatographic signals have been detected for each species, but only between 20 and 50 signals could be identified by the instrument library. Between these, only the most significant signals with high abundance were taken under consideration (peak area $>10^{6}$ units in TIC mode). Moreover, after the subtraction of blank samples, 55 volatiles emitted by the cultures could be chemically classified. The identified compounds together with their increase or decrease of their peaks areas over the whole period of growth are reported in Table 2 for the fungal strain cultivated on MEA medium, and in Table 3 for those cultivated on MEA $15 \%$. The results are expressed as peak area/peak area ${ }_{1}$ ratio, where peak area $_{1}$ is the peak area of the compound at the first detection. This normalization process well reflects the changes of the MVOC's emission concentration.

The only three compounds that all fungal species have in common were isopropyl alcohol and 3-methyl-1-butanol and 2-butanone. Moreover, 2,4-dimethylheptane, 1,4-pentadiene, styrene, ethanol, 2-methyl-1-butanol, acetone, furan and 2-methylfuran were the most detected compounds.

$P$. brevicompactum was the species with the widest range of produced MVOCs, with 34 different compounds. The chemical pattern was mainly composed by acetone and furan, with a lower production of 3-methyl-1-butanol, isopropyl alcohol, styrene, 2-methyl-1-butanol, 2-butanone and ethanol. E. chevalieri emitted 31 different compounds. The principal emission was composed by 1,4-pentadiene, acetone, furan and ethanol, with less presences of 2-butanone, 2-methylfuran, isopropyl alcohol and 3-methyl-1-butanol. For C. cladosporioides, 22 different compounds were detected, with acetone, 2-butene, ethanol, furan and 2-butanone as the main products. A. creber emitted 20 volatiles and 2-butene, ethanol, furan, 1,4-pentadiene, isopropyl alcohol, 1,3-octadiene, 2-butanone, 3-methyl-1-butanol and 2-octen-1-ol were the main composition of its chemical pattern. Finally, 19 compounds were detected for the strain of $P$. chrysogenum, mainly composed by acetone, ethanol and styrene. Other significant emissions were furan, 3-methyl-1-butanol, isopropyl alcohol, 2-bu- 
Table 2

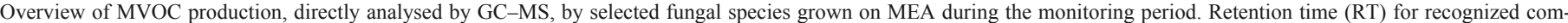

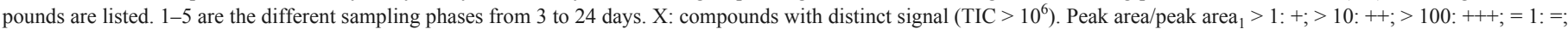
$<1:-$ [peak $_{\text {area }}=$ peak area of the compound at the first measurement].

\begin{tabular}{|c|c|c|c|c|c|c|c|c|c|c|c|c|c|c|c|c|c|c|c|c|c|c|c|c|c|}
\hline \multirow[t]{2}{*}{ Substances } & \multirow[t]{2}{*}{$\begin{array}{l}\mathrm{RT} \\
(\mathrm{min})\end{array}$} & \multicolumn{5}{|c|}{ A. creber } & \multicolumn{5}{|c|}{ C. cladosporioides } & \multicolumn{5}{|c|}{ E. chevalieri } & \multicolumn{4}{|c|}{ P. brevicompactum } & \multicolumn{5}{|c|}{ P. chrysogenum } \\
\hline & & 1 & 2 & 3 & 4 & 5 & 1 & 2 & 3 & 4 & 5 & 1 & 2 & 3 & 4 & 5 & 1 & 2 & 3 & 4 & 5 & 1 & 2 & 3 & 4 \\
\hline Acetamide-2-cyano & 6.34 & & & & & & & $\mathrm{X}$ & - & & & & $\mathrm{X}$ & - & & & & & & & $X$ & & & & \\
\hline Ethanol & 6.48 & & $\mathrm{X}$ & & - & - & $\mathrm{X}$ & + & + & + & + & $\mathrm{X}$ & ++ & +++ & +++ & +++ & $\mathrm{X}$ & + & + & + & + & $X$ & ++ & ++ & +- \\
\hline Acetone & 6.77 & & & & & & $\mathrm{X}$ & + & ++ & ++ & ++ & $\mathrm{X}$ & + & + & + & + & $\mathrm{X}$ & - & + & + & + & $\mathrm{X}$ & + & + & + \\
\hline Isopropyl alcohol & 6.96 & & $\mathrm{X}$ & + & + & + & & $\mathrm{X}$ & + & + & + & & & $\mathrm{X}$ & + & + & $\mathrm{X}$ & & + & + & + & & $\mathrm{X}$ & + & + \\
\hline Furan & 7.06 & $\mathrm{X}$ & + & & & & $\mathrm{X}$ & + & - & - & - & $\mathrm{X}$ & + & ++ & ++ & ++ & $\mathrm{X}$ & + & + & + & + & $X$ & - & - & - \\
\hline Pentane & 7.20 & & & & & & & & & & & & $\mathrm{X}$ & + & + & + & & & $X$ & + & + & & & & \\
\hline 1,4-Pentadiene & 7.32 & $\mathrm{X}$ & ++ & ++ & ++ & ++ & & & & & & $\mathrm{X}$ & + & + & - & - & & $\mathrm{X}$ & - & - & - & $\mathrm{X}$ & + & - & - \\
\hline Cyclopropylcarbinol & 7.38 & & $\mathrm{X}$ & + & + & + & & $\mathrm{X}$ & - & + & + & & & & & & & & 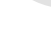 & & & & & & $\mathrm{X}$ \\
\hline Methyl iodide & 7.47 & & $\mathrm{X}$ & - & - & & & & & $\mathrm{X}$ & & & & & & & & $\mathrm{X}$ & + & + & + & $X$ & + & + & + \\
\hline Dimethyl sulfide (DMS) & 7.72 & & & & & & & & & & & $\mathrm{X}$ & $=$ & + & + & + & & 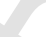 & & & & & & & \\
\hline 1-Propanol & 8.57 & & & & & & & & & & & & & & & & & $X$ & + & $=$ & - & & & & \\
\hline 2-Butanone & 9.21 & $\mathrm{X}$ & + & + & + & + & & & $\mathrm{X}$ & + & - & $\mathrm{X}$ & + & + & + & + & $\mathrm{X}$ & + & ++ & ++ & ++ & $\mathrm{X}$ & + & + & + \\
\hline 1-Hexene & 9.50 & & $\mathrm{X}$ & - & - & - & & & & & & & & & & & & & & & & & & & \\
\hline 2-Butanol, (R) & 9.55 & & & & & & & & & & & & & & & & & & $\mathrm{X}$ & & & & & & \\
\hline 2-Methylfuran & 9.75 & & $\mathrm{X}$ & & & & & & & & & $\mathrm{X}$ & + & ++ & ++ & ++ & 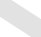 & $\mathrm{X}$ & ++ & ++ & ++ & $\mathrm{X}$ & + & - & - \\
\hline Trichloromethane & 9.95 & & $\mathrm{X}$ & & & & $\mathrm{X}$ & + & + & + & - & $\mathrm{X}$ & + & + & $=$ & + & & & & & & $\mathrm{X}$ & - & - & - \\
\hline 3-Methylfuran & 10.02 & & & & & & & & & & & & & & & & $\mathrm{X}$ & + & + & + & + & & & & \\
\hline Tetrahydrofuran & 10.39 & & $\mathrm{X}$ & & & & & & & & & $\mathrm{X}$ & - & - & & + & & $\mathrm{X}$ & - & + & + & & & & \\
\hline 2-Methyl-1-propanol & 10.46 & & & & & & & & & & & & & & & & $\mathrm{X}$ & & + & + & + & & & & \\
\hline 1-Butanol & 11.37 & & & & & & & & & & & & & & & & & & & $\mathrm{X}$ & & & & & $\mathrm{X}$ \\
\hline Benzene & 11.43 & & & & & & & $\mathrm{X}$ & & & & & & & & & & $\mathrm{X}$ & - & - & & & & & \\
\hline 2-Pentanone & 11.87 & & & & & & & & $\mathrm{X}$ & + & - & & & & & & & $\mathrm{X}$ & $=$ & + & + & & & & \\
\hline 1,3-Dimethylcyclopentane & 12.45 & $\mathrm{X}$ & + & + & + & - & & & & & & & & & & & $\mathrm{X}$ & $=$ & - & - & - & $\mathrm{X}$ & $=$ & - & $=$ \\
\hline 2,5-Dimethylfuran & 12.73 & & & & & & & & & $\mathrm{X}$ & - & & & & & & & & & $\mathrm{X}$ & + & & & $\mathrm{X}$ & + \\
\hline Heptane & 12.75 & & & & & & & & & $\mathrm{X}$ & - & & & & & & & & & $\mathrm{X}$ & - & & & & \\
\hline 2-Heptene & 12.89 & & & & & & & & & & & & & & & & & & & & & $\mathrm{X}$ & + & $=$ & - \\
\hline 3-Methyl-1-butanol & 13.43 & $\mathrm{X}$ & + & + & + & - & $\mathrm{X}$ & + & + & + & + & $X$ & + & + & + & + & $\mathrm{X}$ & + & + & + & + & & $\mathrm{X}$ & + & - \\
\hline 2-Methyl-1-butanol & 13.54 & & & & & & & & & & & & $\mathrm{X}$ & + & + & + & $\mathrm{X}$ & + & + & ++ & + & & $\mathrm{X}$ & + & + \\
\hline Dimethyl disulfide (DMDS) & 13.64 & & & & & & & & & $\mathrm{X}$ & & $\mathrm{X}$ & - & & & & & & & & & & & & \\
\hline 2,5-Dimethylhesane & 13.76 & & & & & & & & & & & $\mathrm{X}$ & - & & & & & & & & & & & & \\
\hline 2,3,4-Trimethylpentane & 14.25 & & & & & & & & & & & $\mathrm{X}$ & 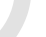 & & & & & & & & & & & & \\
\hline $\begin{array}{l}\text { Propanoic acid, 2-methyl-ethyl } \\
\text { ester }\end{array}$ & 14.25 & & & & & & & & & & & $\mathrm{X}$ & & & & & & $\mathrm{X}$ & + & + & + & & & & \\
\hline Acetic acid, butyl ester & 14.31 & & & & & & & & & & & & & & & & & & & $\mathrm{X}$ & & & & & \\
\hline Toluene & 14.38 & & & & & & & & & & & & & & & & $\mathrm{X}$ & & - & + & & & & & \\
\hline 2,3-Dimethylhexane & 14.63 & & & & & & & & & & & $\mathrm{X}$ & + & + & + & + & & & & & & & & & \\
\hline 2-Octene & 15.09 & & $\mathrm{X}$ & $=$ & + & & & & & $\mathrm{X}$ & - & & & & & & & & & & & & & & \\
\hline 1-Octene & 15.10 & & & & & & & & & + & + & & & & & & & & & & & & & & \\
\hline Octane & 15.36 & & & & $\mathrm{X}$ & + & & & & & & & & & & & & & & & & & & & \\
\hline 2,3,5-Trimethylfuran & 15.49 & & & & & & & & & & & & & & & & & & & $\mathrm{X}$ & + & & & & \\
\hline Tetrachloroethylene & 15.62 & & & & & & & $\mathrm{X}$ & & & & & & $\mathrm{X}$ & + & + & & $\mathrm{X}$ & & & & & & & \\
\hline 1,3-Octadiene & 15.78 & & $\mathrm{X}$ & - & & & & & & & & $\mathrm{X}$ & + & $=$ & + & + & & & & & & & & & \\
\hline 2,4-Dimethylheptane & 15.95 & & & & $\mathrm{X}$ & + & & & & $\mathrm{X}$ & $=$ & $\mathrm{X}$ & - & - & - & - & & & & $\mathrm{X}$ & & & & $\mathrm{X}$ & $=$ \\
\hline Acetic acid, trichloro, ethyl esther & 16.41 & & & & & & & & & & & $\mathrm{X}$ & - & - & - & + & & & & & & & & & \\
\hline 1-Butanol-3-methyl, acetate & 16.79 & & & & & & & & & & & & & & & & & $\mathrm{X}$ & + & + & + & & & & \\
\hline p-Xylene & 16.92 & & & & & & & & & & & $\mathrm{X}$ & - & $=$ & $=$ & + & & & & & & & & & \\
\hline Styrene & 17.35 & & & & & & & & & $\mathrm{X}$ & & & & & & & $\mathrm{X}$ & + & & + & $=$ & & $\mathrm{X}$ & + & + \\
\hline 2-Butoxyethanol & 17.50 & & & & & & & & & & & $\mathrm{X}$ & & + & & - & $\mathrm{X}$ & & & & & & & & \\
\hline 1,5-Dimethyl-1,4-cyclohexadiene & 17.60 & & & & & $\mathrm{X}$ & & & & & & & & & & & & & & & & & & & \\
\hline 2-Octen-1-ol & 18.93 & $\mathrm{X}$ & + & & & - & & & & $\mathrm{X}$ & & $\mathrm{X}$ & & $=$ & & + & & & & & & & & & \\
\hline 3-Octanone & 18.99 & & $\mathrm{X}$ & & + & & & & & $\mathrm{X}$ & & $\mathrm{X}$ & & & & & & & & & & & & & \\
\hline 2,2,6-Trimethyloctane & 19.25 & & & & & & & & & & & $\mathrm{X}$ & - & - & - & - & & & & & & & & & \\
\hline Decane & 19.56 & & & & & & & & & & & $\mathrm{X}$ & - & & - & - & $\mathrm{X}$ & & & & & & & & \\
\hline Limonene & 20.21 & & & & & & & & & & & $\mathrm{X}$ & + & + & $=$ & + & & $\mathrm{X}$ & & & & & & & \\
\hline 2,6,10-Trimethyldodecane & 20.75 & & & & & & & & & & & $\mathrm{X}$ & - & - & - & - & & & & & & & & & \\
\hline
\end{tabular}

tanone, 1,4-pentadiene, 2-methyl-1-butanol, 2,5-dimethylfuran and 2-methylfuran.

Also $A$. penicillioides emitted a wide range of volatiles, 29 different compounds, mainly composed by acetone, 3-octanone, 2-butanone, 1,3-octadiene, 2-octen-1-ol, isopropyl alcohol and cyclopentanone. E. halophilicum produced a total of 23 volatiles mainly composed by 2-butanone and acetone, with less presences of ethyl acetate, 1,4-pentadiene, 3-methyl-1-butanol, ethanol, 2-butanol, isopropyl alcohol, 2-methylfuran and tetrahydrofuran.
Different fungal behaviours were emerged by OxiTop®-C system respirometric analysis, highlighting three mainly clusters: faster growing fungi, slower growing fungi and the slowest growing fungus (Fig. 2). The first group contains A. creber, E. chevalieri, P. brevicompactum and $P$. chrysogenum, that reached the steady-state of oxygen consumption after only 5 days of incubation. Aspergillus penicillioides and $C$. cladosporioides were the components of the second group, which reached the steady-state around 9 days of incubation. The last fungal species, E. halophilicum, was detected as the slowest 
Table 3

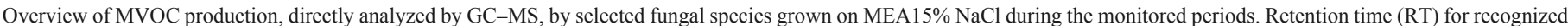

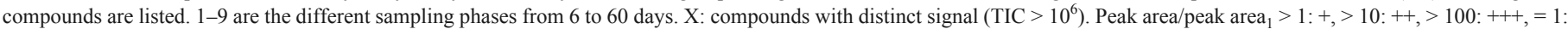
$=,<1:-\left[\right.$ peak area $_{1}=$ peak area of the compound at the first measurement]

\begin{tabular}{|c|c|c|c|c|c|c|c|c|c|c|c|c|c|c|}
\hline \multirow[t]{2}{*}{ Substances } & \multirow[t]{2}{*}{$\mathrm{RT}(\min )$} & \multicolumn{4}{|c|}{ A. penicillioides } & \multicolumn{7}{|c|}{ E. halophilicum } & \multicolumn{2}{|l|}{$\gamma$} \\
\hline & & 1 & 2 & 3 & 4 & 1 & 2 & 3 & 4 & 5 & 6 & 7 & 8 & 9 \\
\hline Acetamide,2-cyano & 6.43 & & & & & $\mathrm{X}$ & + & - & - & - & & & & \\
\hline Ethanol & 6.48 & & & & & $\mathrm{X}$ & + & $=$ & $=$ & $=$ & $=$ & $=$ & + & + \\
\hline Acetone & 6.77 & $\mathrm{X}$ & + & + & + & & $\mathrm{X}$ & + & + & ++ & ++ & ++ & ++ & ++ \\
\hline Isopropyl alcohol & 6.93 & $\mathrm{X}$ & + & + & + & $\mathrm{X}$ & + & + & + & + & + & + & + & +++ \\
\hline Furan & 7.06 & $X$ & - & & & & & & & & & & & \\
\hline Pentane & 7.20 & & $\mathrm{X}$ & - & & & & & & & & ) & & \\
\hline 1,4-Pentadiene & 7.32 & $\mathrm{X}$ & + & + & + & $\mathrm{X}$ & + & + & + & ++ & ++ & ++ & ++ & ++ \\
\hline Methyl iodide & 7.47 & & & & & & & & & & & & & $\mathrm{X}$ \\
\hline 2-Butanone & 9.21 & $\mathrm{X}$ & + & + & + & & $\mathrm{X}$ & ++ & +++ & +++ & +++ & +++ & +++ & +++ \\
\hline 2-Butanol, (R) & 9.55 & & & & & & & & $\mathrm{X}$ & + & + & + & + & + \\
\hline 2-Methylfuran & 9.75 & $X$ & + & & & & & & $\mathrm{X}$ & + & + & + & + & + \\
\hline Ethyl acetate & 9.88 & & & & & & & & & & $\mathrm{X}$ & + & + & + \\
\hline Tetrahydrofuran & 10.39 & $X$ & + & + & + & $\mathrm{X}$ & + & + & + & + & + & + & + & + \\
\hline 3-Methyl-2-butanone & 11.17 & $\mathrm{X}$ & + & - & - & & & & 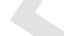 & 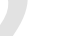 & & & & \\
\hline 1-Butanol & 11.37 & $\mathrm{X}$ & - & & & $\mathrm{X}$ & + & + & + & + & + & + & + & + \\
\hline Heptane & 12.75 & & $\mathrm{X}$ & & & & & & & S & & & & \\
\hline 3-Methyl-3-buten-1-ol & 13.30 & $X$ & + & + & & & & & & & & & & \\
\hline 3-Methyl-1-butanol & 13.43 & $\mathrm{X}$ & + & + & - & $\mathrm{X}$ & + & + & + & + & + & + & + & + \\
\hline 2-Methyl-1-butanol & 13.54 & $\mathrm{X}$ & + & + & + & & & & & & & & & $\mathrm{X}$ \\
\hline 1-Pentanol & 14.25 & $\mathrm{X}$ & + & $=$ & & & & & & & & & & \\
\hline 2,3,4-Trimethylpentane & 14.25 & $\mathrm{X}$ & + & $=$ & & & & & & & & & & \\
\hline Propanoic acid, 2-methyl-, ethyl ester & 14.25 & $\mathrm{X}$ & + & - & & & & & & & & & & \\
\hline Acetic acid, butyl ester & 14.31 & $\mathrm{X}$ & ++ & - & - & & & & 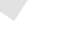 & & & & & \\
\hline Toluene & 14.38 & $\mathrm{X}$ & + & + & + & & & & & $\mathrm{X}$ & + & - & + & + \\
\hline Cyclopentanone & 14.60 & $\mathrm{X}$ & + & + & + & & & & & $\mathrm{X}$ & + & $=$ & + & + \\
\hline 2,3-Dimethylpentane & 14.63 & & & & $\mathrm{X}$ & & & & & & & & & \\
\hline 2-Penten-1-ol & 14.69 & & & & $\mathrm{X}$ & & & & & & & & & \\
\hline 1-Octene & 15.10 & $X$ & + & - & & & & & & & & & & \\
\hline Tetrachloroethylene & 15.62 & & & & & $\mathrm{X}$ & + & + & & & & & & \\
\hline 1,3-Octadiene & 15.78 & $\mathrm{X}$ & + & - & - & & & & & & & & & \\
\hline Ethylbenzene & 16.74 & & $\mathrm{X}$ & + & & $\mathrm{X}$ & ++ & $=$ & + & + & $=$ & $=$ & + & ++ \\
\hline 1-Butanol,3-methyl, acetate & 16.79 & & & & & & & & & & & & & $X$ \\
\hline p-Xylene & 16.92 & & $\mathrm{X}$ & - & & & $\mathrm{X}$ & - & - & - & & & & \\
\hline Styrene & 17.35 & & $\mathrm{X}$ & $=$ & & & $\mathrm{X}$ & & & - & & & & \\
\hline o-Xylene & 17.47 & & $\mathrm{X}$ & - & & & $\mathrm{X}$ & & - & - & & & & \\
\hline 2-Butoxyethanol & 17.50 & & & & & & & & & & & & & $\mathrm{X}$ \\
\hline 2-Octen-1-ol & 18.93 & $\mathrm{X}$ & - & - & & & & & & & & & & \\
\hline 3-Octanone & 18.99 & $X$ & + & + & - & & & & & & & & & \\
\hline
\end{tabular}

growing fungus, because it started to consume oxygen after 19 days from the inoculation.

\section{Discussion}

The investigation was principally focused on the total MVOC detection with the innovative direct sampling, in order to avoid any pre-chemical selection due to the use of passive sampling devices. However, the use of only one kind of medium for each fungal species (MEA or MEA15\%) probably limited the MVOC emission. In fact, it is well-known how the production is strictly growth substrate-dependent (Matysik et al., 2009; Moularat et al., 2008) and several kinds of culture media, included contaminated building materials or settled dust samples, were generally included in the experiments (Korpi et al., 1997; Matysik et al., 2008; Vishwanath et al., 2011; Wady and Larsson, 2005; Wady et al., 2003; Wilkins et al., 2000). On the other hand, working with Cultural Heritage has often limitations and, because of the preciousness of the artefacts, most of the applied methods need to be non-invasive (Kostadinovska, 2015; Manente et al., 2012). This study investigated for the first time the MVOC production ability of the most frequent fungi directly involved with book contamination, identifying specific chemical patterns for each fungal species. For the common indoor fungi and already known MVOC-producer, as $C$. cladosporioides, $P$. brevicompactum and $P$. chrysogenum (Samson et al., 2004), several specie-specific compounds were detected. C. cladosporioides emitted 1-octene, 3-methyl-1-butanol, 2-octen-1-ol, 2-pentanone and 3-octanone, as already observed in previous studies (Matysik et al., 2008, 2009; Sunesson et al., 1995). For $P$. brevicompactum, 2-methyl-1-propanol, acetone, 3-pentanon, 2-butanone and 3-methylfuran can be considered as possible markers (Börjesson et al., 1992), while the compounds 1-heptene, 2-butanol, 2-methyl-1-butanol and 3-methyl-1-butanol were characteristic for $P$. chrysogenum (Matysik et al., 2008, 2009; Wilkins et al., 2000).

Few records in literature are available for the xerophilic fungi A. penicillioides and E. chevalieri. Similar to our results, Wady et al. (2003) detected 2-pentanol, 3-octanone, 1-octen-3-ol and 2-methyl-1-butanol for cultures of $A$. penicillioides isolated from mineral wood onto DG18 medium. For E. chevalieri, the only similar compound compared to Elke et al. (1999) was 3-methylbutan-1-ol regarding the analysis of Eurotium species isolated from indoor dust samples on DG18 medium.

A lack of knowledge about MVOC production exists for the species $A$. creber, due to its recent identification among the $A s$ - 

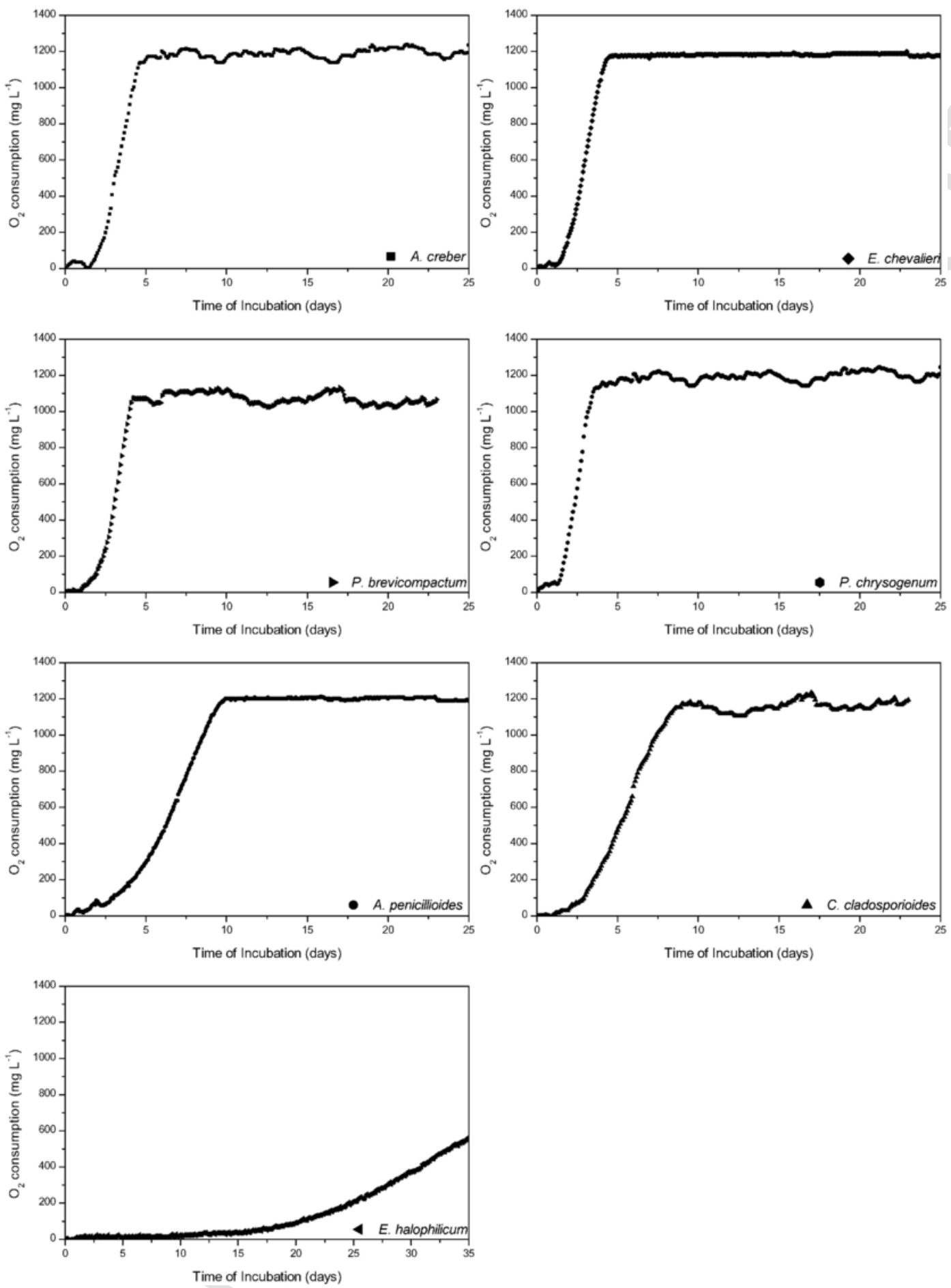

Fig. 2. Overview of respirometric trends of all selected fungal species.

pergillus section Versicolores group (Juriević et al., 2012). Considering the MVOC production of a well-known species belonged to the same group, A. versicolor, A. creber resulted similar for the emission of 1,3-pentadiene, 1-octene, 3-methyl-1-butanol, 2-octene-1-ol, 3-octanone and 3-methylfuran (Fiedler et al., 2001; Polizzi et al., 2012; Schuchardt and Kruse, 2009; Sunesson et al., 1995). As reported by Matysik et al. (2008) for $A$. versicolor, the temporary trend of the main emission by $A$. creber recorded a maximum peak around 6 days after incubation, followed by a general decrease.
For E. halophilicum no data of its MVOC production is available in literature. The interest around this fungal species increased in the last few years because of its spread identification in connection with strong contaminated repositories and archives around Italy (Micheluz et al., 2015; Montanari et al., 2012; Pinzari and Montanari, 2011). In a previous study, Micheluz et al. (2016) have characterized this fungus for its secondary metabolite production, and this is the first report of its MVOC production ability. On MEA15\%, E. halophilicum emitted a wide range of volatile compounds, which increases clearly fol- 
lowing its growth during the entire monitoring period (60 days). The chemical pattern was mainly composed by acetone and 2-butanone, with lower presences of 1,4-pentadiene, ethyl acetate, 2-butanol, 3-methyl-1-butanol, tetrahydrofuran and 2-methylfuran (Fig. 3). Among all of these compounds, the time trend for 2-butanone and
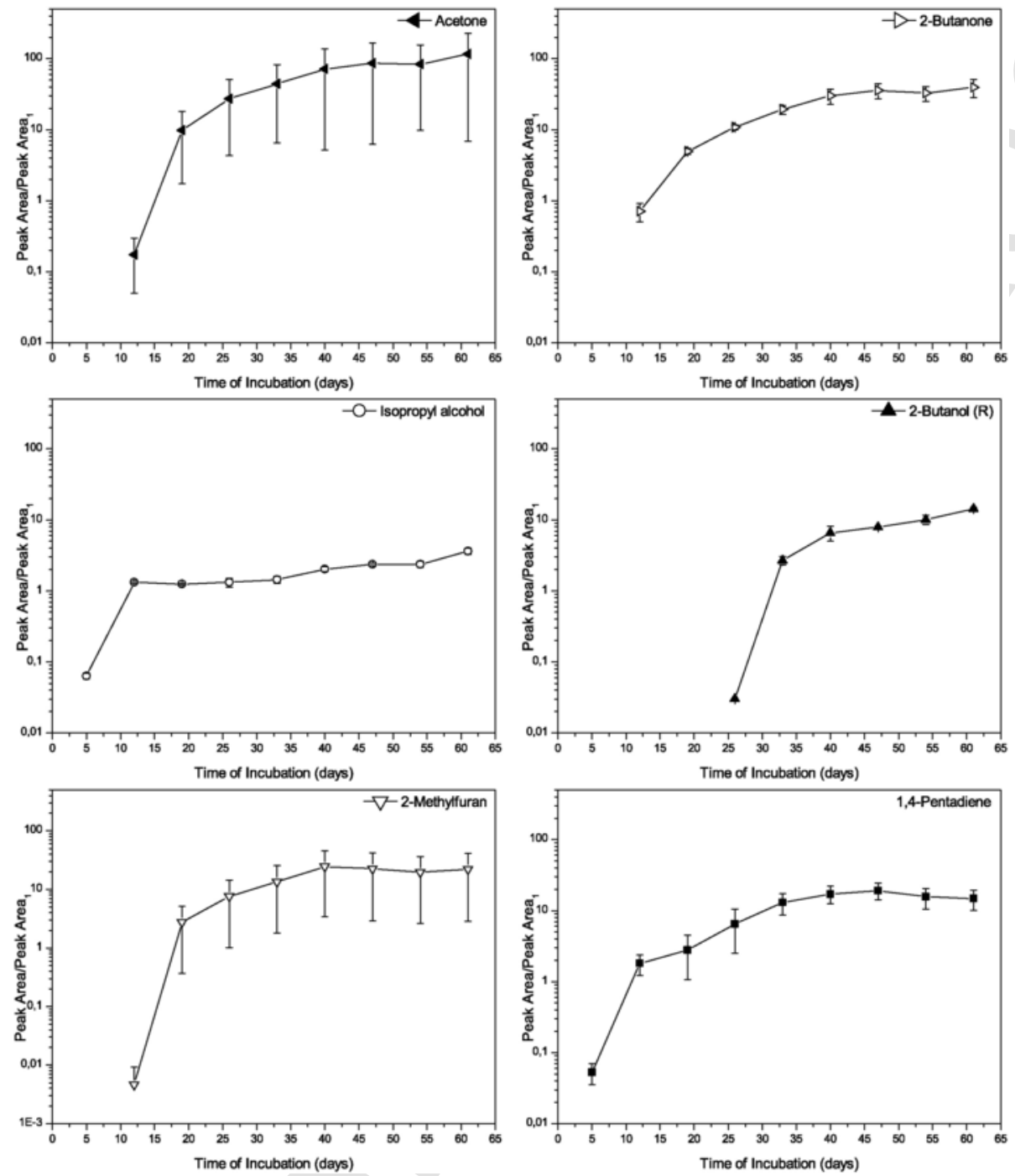

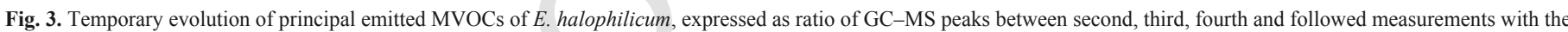
peak area of the first measurement. The values are the averages of three replicates $(n=3)$.
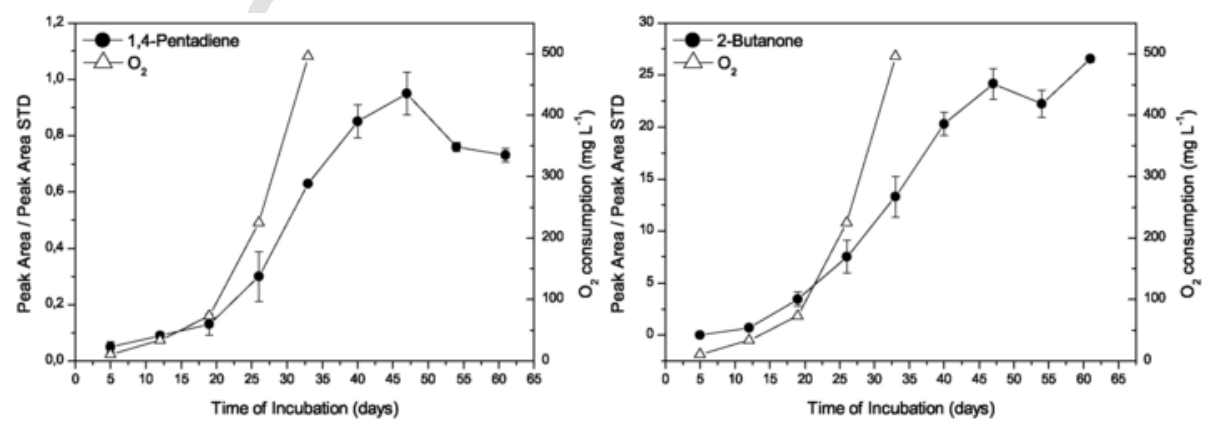

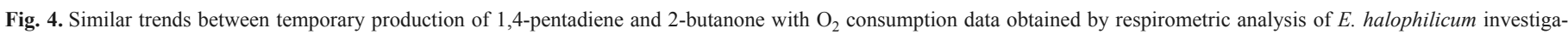
tions. The chemical values are the averages of three replicates $(n=3)$. 
production as products of an active fungi metabolism, also along the entire monitoring period.

The MVOC analysis of the principal mycoflora of a contaminated indoor environment helped us to focus our research toward specific chemical proxies. The temporal monitoring has confirmed that the fungi started to produce volatile compounds from the first stage of their development but also during their vegetative phase. This is a confirmation about the variable chemical production, also in a limited growth conditions.

The next step is the analysis of old fungal colonies in order to characterize the variation of volatile production during all fungal vital cycles.

This analysis could be a faster alternative to detect mould presence in indoor environments. In this way, we can focus our attention towards selected MVOCs in similar preservation studies, determining also the age of the contamination and selecting the best conservation intervention.

\section{Acknowledgements}

The authors thank Dr. Cinzia Lanzoni and Franco Schiavon of the Dipartimento Provinciale di Venezia, Agenzia Regionale per la Prevenzione e Protezione Ambientale del Veneto for their support with microbiological and chemical analyses and Archt. Elena Torresan for her graphical contribution.

\section{References}

Börjesson, T., Stöllman, U., Schnürer, J., 1992. Volatile metabolites produced by six fungal species compared with other indicators of fungal growth on cereal grains. Appl. Envrion. Microbiol. 58, 2104-2111.

Cabral, J.P.S., 2010. Can we use indoor fungi as bioindicators of indoor air quality? Historical perspectives and open questions. Sci. Total Environ. 408, 4285-4295.

Christensen, C.M., Papavizas, G.C., Benjamin, C.R., 1959. A new halophilic species of Eurotium. Mycologia 51, 636-640.

Elke, K., Begerow, J., Oppermann, H., Krämer, U., Jermanna, E., Dunemanna, L., 1999. Determination of selected microbial volatile organic compounds by diffusive sampling and dual-column capillary GC-FID—a new feasible approach for the detection of an exposure to indoor mould fungi?. J. Environ. Monitor. 1, 445-452.

EPA TO-15, 1999. Compendium of methods for the determination of toxic organic compounds, compendium method TO-15, determination of volatile organic compounds (VOCs) in air collected in specially-prepared canister and analyzed by gas chromatography/mass spectrometry (GC/MS (EPA/625/R-96/010b) second ed..

Fenech, A., Strilič, M., Kralj Cigić, I., Levart, A., Gibson, L.T., de Bruin, G., Ntanos, K., Kolar, J., Cassar, M., 2010. Volatile aldehydes in libraries and archives. Atmos. Environ. 44, 2067-2073.

Fiedler, K., Schuetz, E., Geh, S., 2001. Detection of microbial volatile organic compounds (MVOCs) produced by moulds on various materials. Int. J. Environ. Health 204, 111-121.

Gibson, L.T., Ewlad-Ahmed, A., Knight, B., Horie, V., Mitchell, G., Robertson, C.J., 2012. Measurement of volatile organic compounds emitted in libraries and archives: an inferential indicator of paper decay?. Chemistry Central Journal 6-42.

Joblin, Y., Moularat, S., Anton, R., Bousta, F., Orial, G., Robine, E., Picon, O., Bourouina, T., 2010. Detection of moulds by volatile organic compounds: Application to heritage conservation. Int. Biodeter. Biodegr. 64, 210-217.

Juriević, Z., Peterson, S.W., Horn, B.W., 2012. Aspergillus section Versicolores: nine new species and multilocus DNA sequence based phylogeny. IMA Fungus $3,59-79$

Korpi, A., Järnberg, J., Pasanen, A.-L., 2009. Microbial Volatile Organic Compounds. Crit. Rev. Toxicol. 39, 139-193.

Korpi, A., Pasanen, A.-L., Pasanen, P., Kalliokoski, P., 1997. Microbial growth and metabolism in house dust. Int. Biodeter. Biodegr. 40, 19-27.

Kostadinovska, M., 2015. In: Non-destructive characterization of paper artifacts in conservation treatments. History and Archaeology 10.18638/quaesti.2015.3.1.215 The 3rd Virtual Multidisciplinary Conference 7.11.2015.

Kuske, M., Romain, A.-C., Nicolas, J., 2005. Microbial volatile organic compounds as indicators of fungi. Can an electronic nose detect fungi in indoor environments? Build. Environ. 40, 824-831.

Larsen, F.O., Clementsen, P., Hansen, M., Maltbaek, N., Ostenfeldt-Larsen, T., Nielsen, K.F., Gravesen, S., Skov, P.S., Norn, S., 1998. Volatile organic com- pounds from the indoor mould Trichoderma viride cause histamine release from human bronchoalveolar cells. Inflamm. Res. 47, S5-S6.

Lattuati-Derieux, A., Bonnassies-Termes, S., Lavédrine, B., 2004. Identification of volatile organic compounds emitted by a naturally aged book using solid-phase microextraction/gas chromatography/mass spectrometry. J. Chromatogr. A $1026,9-18$.

Manente, S., Micheluz, A., Ganzerla, R., Ravagna, G., Gambaro, A., 2012. Chemical and biological characterization of paper: a case study using a proposed methodological approach. Int. Biodeter. Biodegr. 74, 99-108.

Matysik, S., Herbarth, O., Mueller, A., 2008. Determination of volatile metabolites originating from mould growth on wall paper and synthetic media. J. Microbiol. Meth. 75, 182-187.

Matysik, S., Herbarth, O., Mueller, A., 2009. Determination of microbial volatile organic compounds (MVOCs) by passive sampling onto charcoal sorbents. Chemosphere $76,114-119$

Meyer, H.W., Larsen, F.O., Jacobi, H.H., Poulsen, L.K., Clementsen, P., Gravesen, S., Gyntelberg, F., Norn, S., 1998. Sick building syndrome: association of symptoms with serum IgE specific to fungi. Inflamm. Res. 47, S9-S10.

Micheluz, A., Manente, S., Tigini, V., Prigione, V., Pinzari, F., Ravagnan, G., Varese G.C., 2015. The extreme environment of a library: xerophilic fungi inhabiting indoor niches. Int. Biodeter. Biodegr. 99, 1-7.

Micheluz, A., Sulyok, M., Manente, S., Krska, R., Varese, G.C., Ravagnan, G.. Fungal secondary metabolite analysis applied to cultural heritage: the case of a contaminated library in Venice. World Mycotoxin J. 9(3), 2016, 397-407.

Montanari, M., Melloni, V., Pinzari, F., Innocenti, G., 2012. Fungal biodeterioration of historical library materials stored in Compactus movable shelves. Int. Biodeter. Biodegr. 75, 83-88.

Moularat, S., Robine, E., Ramahlo, O., Oturam, M.A., 2008. Detection of fungal development in closed spaces through the determination of specific chemical targets. Chemosphere 72, 224-232.

Pereira, P., Enguita, F.J., Ferreira, J., Leitão, A.L., 2014. DNA damage induced by hydroquinone can be prevented by fungal detoxification. Toxicology Reports $1,1096-1105$.

Pinzari, F., Montanari, M., 2011. Mould growth on library materials stored in compactus-type shelving units. In: Abdul-Wahab Al-Sulaiman, S.A. (Ed.), Sick Building Syndrome: Public Buildings and Workplaces. Springer-Verlag, Berlin Heidelberg, pp. 193-206.

Pinzari, F., Fanelli, C., Canhoto, O., Magan, N., 2004. Electronic nose for the early detection of moulds in libraries and archives. Indoor Built Environ. 13, 387-395.

Polizzi, V., Adams, A., Malysheva, S.V., De Saeger, S., Van Peteghem, C., Moretti., A., Picco, A.M., De Limpe, N., 2012. Identification of volatile markers for indoor fungal growth and chemotaxonomic classification of Aspergillus species. Fungal Biology 116, 941-953.

Polizzi, V., Delmulle, B., Adams, A., Moretti, A., Susca, A., Picco, A.M., Rosseel, Y., Kindt, R., Van Bocxlaer, J., De Kimpe, N., Van Peteghem, C., De Saeger, S., 2009. Fungi, mycotoxins and microbial volatile organic compounds in mouldy interiors from water-damaged buildings. J. Environ. Monitor. 11, 1849-1858.

Rovea, M., Lanzoni, C., Zorzi, D., Formenton, G., Schiavon, F., Baldin, M., 2013. Composti organici volatili prodotti da muffe. La Chimica \& l'Industria. (Ott./Nov. 13, 95-101).

Samson, R.A., Hoekstra, E.S., Frisvad, J.C., 2004. Introduction to Food and Airborne Fungi. ASM Press, US

Schuchardt, S., Kruse, H., 2009. Quantitative volatile metabolite profiling of common indoor fungi: relevancy for indoor air analysis. J. Basic Microb. 49, 350-362.

Sterflinger, K., 2010. Fungi: their role in deterioration of cultural heritage. Fungal Biol Rev. 24, 47-55.

Strilič, M., Menart, E., Kralj Cigić, I., De Bruin, G., Kolar, J., Cassar, M., 2010. Emission of volatiles and reactive oxygen species during degradation of iron gall ink. Polym. Degrad. Stab. 95, 66-71.

Strilič, M., Thomas, J., Trafela, T., Cséfalváyova, L., Kralj Cigić, I., Kolar, J., Cassar, M., 2009. Material degradomics: on the smell of old books. Anal. Chem. 81, 8617-8622.

Sunesson, A.-L., Vaes, W.H.J., Nilsoon, C.-A., Blomquist, G., Andersson, B., Carlson, R., 1995. Identification of volatile metabolites from five fungal species cultivated on two media. Appl. Environ. Microb. 61, 2911-2918.

Vishwanath, V., Sulyok, M., Weingart, G., Kluger, B., Täubel, M., Mayer, S., Schuhmacher, R., Krska, R., 2011. Evaluation of settled floor dust for the presence of microbial metabolites and volatile anthropogenic chemicals in indoor environments by LC-MS/MS and GC-MS methods. Talanta 85, 2027-2038.

Wady, L., Larsson, L., 2005. Determination of microbial volatile organic compounds adsorbed on house dust particles and gypsum board using SPME/GC-MS. Indoor Air 15, 27-32

Wady, L., Bunte, A., Pehrson, C., Larsson, L., 2003. Use of a gas chromatography-mass spectrometry/solid phase microextraction for the identification of MVOCs from moldy building materials. J. Microbiol. Meth. 52, 325-332.

Wessén, B., Schoeps, K.-O., 1996. Microbial volatile organic compounds - what substances can be found in sick buildings?. Analyst 121, 1203-1205. 
Wilkins, K., Larsen, K., Simkus, M., 2000. Volatile metabolites from mold growth on building materials and synthetic media. Chemosphere 41, 437-446.

Willcock, J., Magan, N., 2001. Impact of environment factors on fungal respiration and dry matter losses in wheat straw. J. Stored Prod. Res. 37, 35-45.
Zyska, B., 1997. Fungi isolated from library materials: a review of the literature. Int. Biodeterior. Biodegrad. 40, 43-51. 